\title{
Characterization of Soil Fertility for Wheat Production at Shiebench District in Bench Maji Zone, Southern Ethiopia
}

\author{
Zenebu Belay ${ }^{1 *}$, Heluf Gebrekidan ${ }^{2}$ and Wassie Haile ${ }^{2}$ \\ ${ }^{1}$ MizanTepi University, Ethiopia \\ ${ }^{2}$ Haramaya University, Ethiopia
}

Submission: December 01,2017; Published: April 30, 2018

*Corresponding author: Zenebu Belay, College of Agriculture and Natural Resources, MizanTepi University, Mizan Teferi, Ethiopia, Email: zenibelay2003@gmail.com

\begin{abstract}
In Ethiopia, declining soil fertility presents a major challenge to bring sustainable productivity. An experiment was conducted during the 2011 main cropping season at Bakbes and Ziyagn experimental sites of Shiebench District of Bench Maji Zone with the objective of soil fertility characterization for wheat production. One fresh soil profile pit was opened at each site; and soil samples of each layer of the profile and composite surface soils were analyzed for selected soil physicochemical properties. Profile soils of both Bakbes and Ziyagn sites have clay textural class, where as the mean particle size distribution of the composite surface soils of both sites revealed clay loam soil texture. The pH $\left(\mathrm{H}_{2} \mathrm{O}\right)$ values of the profiles varied from 4.90 to 5.40 and from 4.60 to 4.90 at Bakbes and Ziyagn sites, respectively while the mean pH of the composite surface soils of Bakbes and Ziyagn sites were 5.63 and 4.93, respectively. The mean OM contents of the composite surface soils were 6.24 and $5.90 \%$ at Bakbes and Ziyagn sites, respectively. The total $\mathrm{N}$ contents of the soil profiles varied from 0.18 and $0.17 \%$ to 0.57 and $0.61 \%$ at Bakbes and Ziyagn sites, respectively. The mean total Nand available P contents of the composite surface soils were $0.42 \%$ and $16.32 \mathrm{mg} \mathrm{kg}^{-1}$ at Bakbes and $0.40 \%$

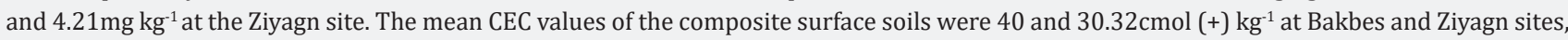
respectively while the mean exchangeable Al and acidity contents of the composite surface soils were (0.16 and 0.29$)$ and (1.44 and 2.13) $\mathrm{cmol}(+)$ $\mathrm{kg}^{-1}$ at Bakbes and Ziyagn sites, respectively. In conclusion, the use of various types and methods of amendments in combination with inorganic fertilizers and use of non-acidifying fertilizers are suggested to minimize the negative effects of soil acidity.
\end{abstract}

Keywords: Soil fertility; Composite sample soil; Profile soil; Wheat

\section{Introduction}

In Ethiopia, declining soil fertility presents a major challenge to bring about increased and sustainable productivity in order to feed the ever-increasing population of the country. As a result, millions are suffering from poverty and malnutrition. Eyasu [1] indicated that under increasing demographic pressure, cultivation becomes permanent. In many cases, removal of vegetation covers, depletion of soil nutrients and $\mathrm{OM}$, and accelerated soil erosion have all led to the drastic decline in soil productivity. Soil acidity and soil fertility declines are forms of soil degradation adversely affecting sustainable crop production in Ethiopia in general and in the Southern Nations-Nationalities' and People's Regional State (SNNPRS) in particular.

Soil fertility is a function of its physical, chemical and biological properties on which we have to have not only quantitative but also qualitative information to formulate the appropriate fertility management programs. As soil fertility is the most valuable asset, to maintain where it is high and to improve where it is low, assessment is a prerequisite to rate soils on the basis of their fertility status. Generally, the depletion of soil fertility due to continual nutrient mining by crop removal without adequate replenishment, combined with imbalanced plant nutrition practices has posed a serious threat to agricultural production [2].

Soil acidity is one of the factors limiting wheat production in the Shiebench District where the present study was conducted. Wheat is one of the major important small cereal crops in Ethiopia. As a result, Ethiopia is one of the largest wheat producers among the countries in the Sub-Saharan Africa. However it was only recently that the area under wheat has surpassed that of barley Fasil et al. [3] because of its significance as a cash crop, a high level of production per unit area, and its role in supplying the dietary requirements of peasant farmers. Wheat is grown in the highlands of the country at altitude ranging from 1500 to 
3000 meters above sea level (masl), situated between 6-16 ${ }^{\circ}$ $\mathrm{N}$ latitude and $35-42^{\circ} \mathrm{E}$ longitude. However, the most suitable agro-ecological zones of wheat fall between 1900 and 2700masl [4]. Wheat crop can be grown in most locations where annual rainfall ranges from $250-1750 \mathrm{~mm}$ [4]. Wheat is produced across a wide range of soil conditions, although it is best adapted to fertile, well-drained silt loam and clay loam soils.

However, information about the status of soil fertility and the recommended multi-nutrient fertilizer rates and sources along with micronutrients and chemical amendments to improve acid soil properties for different crops grown on different soil types in the country at large and the specific study area of Shiebench District, Southern Ethiopia in particular is very much limited. Accordingly, there is a need to evaluate the status of soil fertility of the study area for the improved production of wheat. Therefore, the present study was proposed with the following specific objective:

a. To characterize the fertility status of the soils at the study sites (Bakbes and Ziagn, SNNPRS) based on their selected pysico-chemical properties.

\section{Materials and Methods}

\section{Descriptions of the study area}
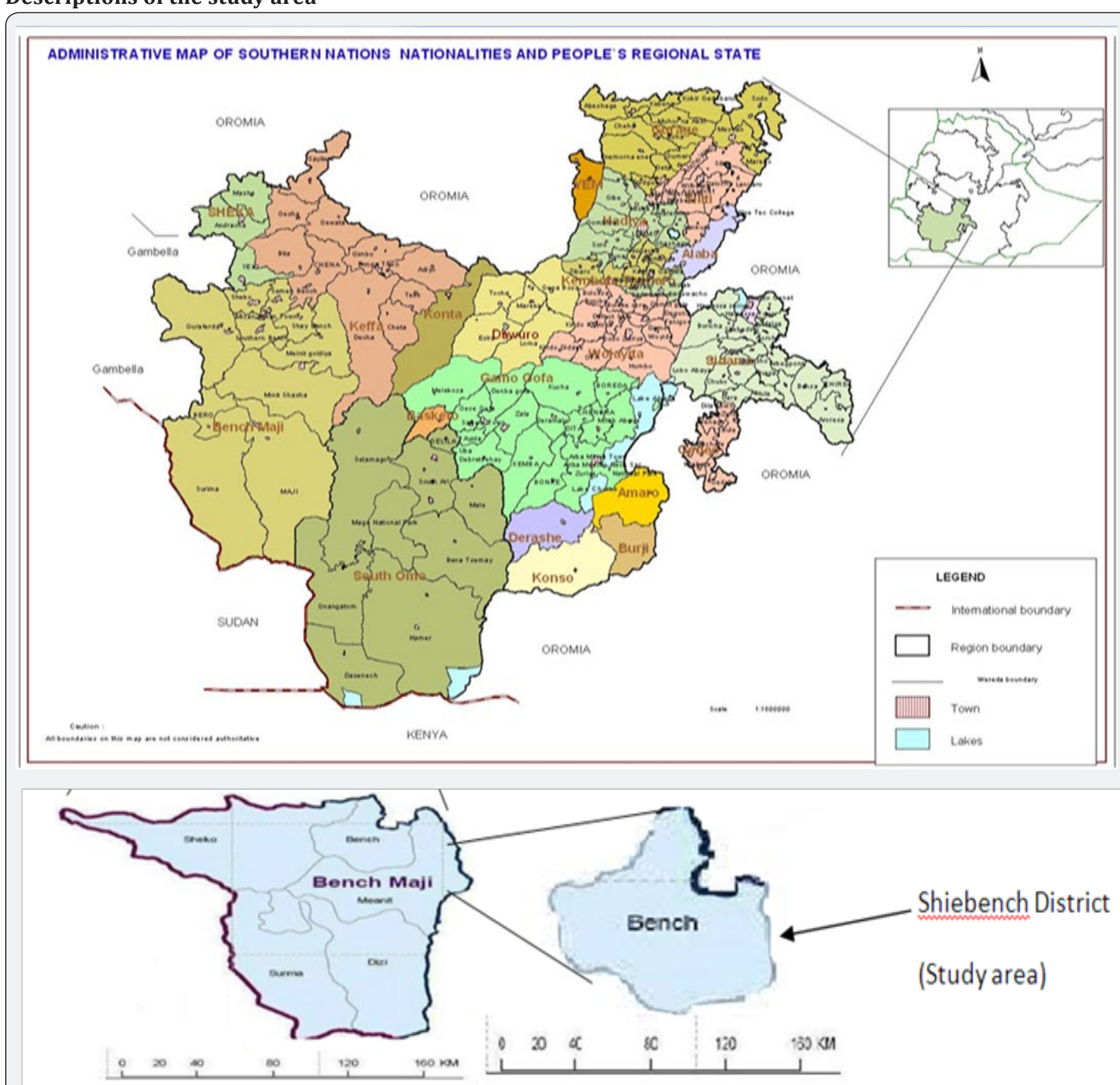

Figure 1: Map of Bench Maji Zone and location of the study area. 
The field experiment was conducted during the 2011 main cropping season under rainfed condition to characterize the fertility status of the soils at the study sites (Bakbes and Ziagn). The study was conducted on soils of Shiebench District in Bench Maji Zone of the SNNPRS which is located at $650 \mathrm{~km}$ far from
Addis Ababa to the southwest direction, and $55 \mathrm{~km}$ northeast direction to the capital of Bench Maji Zone; MizanTeferi, on the way from Addis Ababa to MizanTeferi (Figure 1). The area has an elevation ranging between 1600 and 2400 masl.

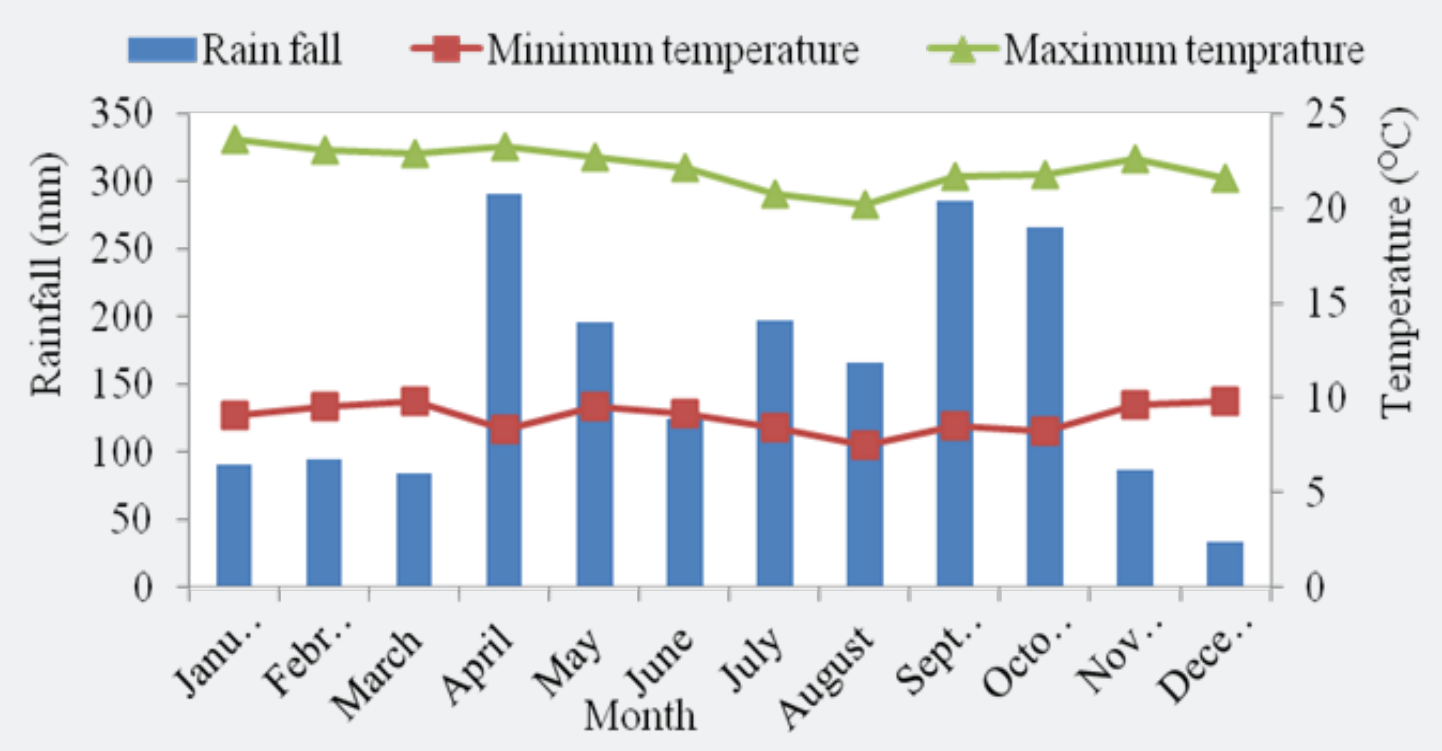

Figure 2: Annual rainfall (mm), minimum and maximum temperatures in 2011.

The study area is characterized by bi-modal rainfall pattern. The area receives a mean annual rainfall of $1570 \mathrm{~mm}$ (Figure 2) and the mean monthly minimum and maximum temperatures are 9.3 and $22.9^{\circ} \mathrm{C}$, respectively (Figure 2) (Teppi Metrological Station). Maize, wheat, teff, sorghum, rice and faba beans are among the dominant crops widely grown in the study areas while peas and some oil crops are also grown.

\section{Soil profile description, sample preparation and analysis}

Profile description and soil sample preparation:The study was conducted at two different sites, and on each site a soil profile pit of $1.5 \mathrm{~m}$ width, $1 \mathrm{~m}$ length and $2 \mathrm{~m}$ depth was opened to describe the morphology and soil samples were taken from each layer of both profiles for laboratory characterization of selected soil physical and chemical properties. Besides, composite surface samples were taken using auger from the experiment area from a depth of $0-15 \mathrm{~cm}$.

The composite surface soil and soil profile samples collected were air dried at room temperature by spreading on plastic sheet. After drying, the samples were crushed in a metal mortar and pestle and sieve through a $2 \mathrm{~mm}$ sieve and through $0.5 \mathrm{~mm}$ sieve for total $\mathrm{N}$ and $\mathrm{OM}$ determination. Finally, the samples (surface and profile) were analyzed in National Soil Testing Laboratory for soil texture, $\mathrm{pH}, \mathrm{OM}$, total $\mathrm{N}$, available $\mathrm{P}$, available $\mathrm{K}, \mathrm{CEC}$, exchangeable bases, and exchangeable acidity (exchangeable $\mathrm{Al}$ $+\mathrm{H})$ and micronutrients ( $\mathrm{Zn}, \mathrm{Cu}, \mathrm{Mn}$ and $\mathrm{Fe})$.

Analysis of soil physical and chemical properties:Soil texture was determined using the Bouyoucos hydrometer method. The soil $\mathrm{pH}$ was measured potentiometrically in the supernatant suspension of a 1:2.5 soil to water ratio using a $\mathrm{pH}$ meter. The Sahlemedhin \& Taye [5] wet digestion method was used to determine soil organic carbon content and percent soil OM was obtained by multiplying percent soil organic carbon by a factor of 1.724. Similarly, total N was analyzed using the Kjeldahl digestion and distillation method as described Sahlemedhin \& Taye [5] by oxidizing the OM in concentrated sulfuric acid solution $(0.1 \mathrm{~N} \mathrm{H} 2 \mathrm{SO} 4)$ and converting the $\mathrm{N}$ into $\mathrm{NH} 4+$ as ammonium sulfate. Determination of available $\mathrm{P}$ was carried out by the Olsen method using sodium bicarbonate as extracting solution [6].

Exchangeable bases ( $\mathrm{Ca}, \mathrm{Mg}, \mathrm{K}$ and $\mathrm{Na}$ ) of the soils were extracted by ammonium acetate (1M NH4OAc at $\mathrm{pH}$ 7) solution. Exchangeable $\mathrm{Ca}$ and $\mathrm{Mg}$ in the extracts were determined by atomic adsorption spectrophotometer while exchangeable $\mathrm{K}$ and $\mathrm{Na}$ in the extracts were measured by flame photometer [7]. The CEC of soil was determined from the ammonium acetate saturated samples through distillation and measurement of ammonium using the modified Kjeldahl procedure as described by Okalebo et al. [7] and reported as CEC. Finally, Percent base saturation (PBS) was computed as the percentage of the sum of exchangeable bases to the CEC of the soil.

The base titration method which involves extraction of soil samples with $1 \mathrm{M} \mathrm{KCl}$ solution and titration with $0.02 \mathrm{M} \mathrm{NaOH}$ using phenolphthalein solution with a permanent pink end point as an indicator, with alternate stirring was employed to determine exchangeable acidity. Finally, the amount of base $(\mathrm{NaOH})$ consumed was considered equivalent to the total 
exchangeable acidity (exchangeable $\mathrm{Al}+\mathrm{H}$ ) as described by Okalebo et al. [7]. Extractable (available) micronutrients (Zn, $\mathrm{Cu}, \mathrm{Mn}$ and $\mathrm{Fe}$ ) in the soil samples were extracted with DTPA as described by Sahlemedhin \& Taye [5]. The amounts of the micronutrients in the extracts were determined by atomic absorption spectrophotometer in comparison with standards at 248.3 , 279.5, 324.7 and 213.9nm wave lengths for $\mathrm{Fe}, \mathrm{Mn}, \mathrm{Cu}$, and Zn, respectively.

\section{Results and Discussion}

\section{Physicochemical properties of soils of the study srea}

Soil texture: In the present study, there were no differences in textural classes of the profile samples of both sites (Bakbes and Ziyagn). Accordingly, both sites had clay textural class throughout their depths (Table 1), whereas the mean texture of the composite surface soils of both sites was clay loam, those soils which have clay loam textural classes are best adaptable for wheat. Generally, the clay content of the soil profile characterized at the Bakbes site increased consistently with increasing soil profile depth from $52 \%$ in the surface layer to
$92 \%$ in the subsurface $(80-1350 \mathrm{~cm})$ and slightly decreased to $90 \%$ at the extreme subsoil $(135-190 \mathrm{~cm})$ depth of the profile. On the contrary, the sand and silt contents of the profile decreased with depth from 21 and $27 \%$ in the surface layer to 1 and $7 \%$ in the subsoil $(80-135 \mathrm{~cm})$ depth of the profile, respectively.

Similarly, the clay content of the soil at the Ziyagn site increased consistently with increasing soil profile depth from $44 \%$ in the surface layer to $68 \%$ at the lower subsoil $(85-145 \mathrm{~cm})$ layer and then declined to $66 \%$ at the extreme subsoil (145$195 \mathrm{~cm}$ ) depth of the profile (Table 1). Contrary to clay, the sand and silt contents of the profile at the same site decreased with depth from $25 \%$ in the surface layer to $9 \%$ in the bottom layer of the profile for sand and from $31 \%$ in the surface layer to $23 \%$ at the subsoil depth of $(85-145 \mathrm{~cm})$ and then increased again to $25 \%$ in the bottom layer of the profile for the silt fraction. The increase in clay content and decrease in the sand and silt fractions with increasing soil depth except the bottom subsurface layers observed in these profiles might be attributed to the translocation of clay from the surface to subsurface horizons.

Table 1: Selected physicochemical properties of the soil profiles and composite surface soil samples of the study areas.

\begin{tabular}{|c|c|c|c|c|c|c|c|c|}
\hline \multirow{2}{*}{$\begin{array}{l}\text { Depth } \\
(\mathrm{cm})\end{array}$} & \multicolumn{3}{|c|}{ Particle size (\%) } & \multirow{2}{*}{\begin{tabular}{c|} 
Textural \\
class
\end{tabular}} & \multirow{2}{*}{$\begin{array}{c}\text { pH } \\
\left(\mathrm{H}_{2} \mathrm{O}\right)\end{array}$} & \multirow{2}{*}{$\begin{array}{l}\mathbf{O M} \\
(\%)\end{array}$} & \multirow{2}{*}{$\begin{array}{c}\text { Total N } \\
\%)\end{array}$} & \multirow{2}{*}{$\frac{\text { Av. } \mathbf{P}}{\left(\mathrm{mg} \mathrm{kg}^{-1}\right)}$} \\
\hline & Sand & Silt & Clay & & & & & \\
\hline \multicolumn{9}{|c|}{ Soil profile at Bakbes site } \\
\hline $0-35$ & 21 & 27 & 52 & Clay & 5.2 & 6.27 & 0.57 & 3.66 \\
\hline $35-80$ & 5 & 19 & 76 & Clay & 5.4 & 4.34 & 0.41 & 1.72 \\
\hline $80-135$ & 1 & 7 & 92 & Clay & 5 & 1.55 & 0.21 & 1.14 \\
\hline $135-190$ & 1 & 9 & 90 & Clay & 4.9 & 0.76 & 0.18 & 1.72 \\
\hline \multicolumn{9}{|c|}{ Soil profile at Ziyagn site } \\
\hline $0-30$ & 25 & 31 & 44 & Clay & 4.9 & 6.18 & 0.61 & 2.26 \\
\hline $30-85$ & 15 & 37 & 48 & Clay & 4.9 & 5.2 & 0.49 & 2.34 \\
\hline $85-145$ & 9 & 23 & 68 & Clay & 4.9 & 1.95 & 0.21 & 3.38 \\
\hline $145-195$ & 9 & 25 & 66 & Clay & 4.9 & 1.59 & 0.17 & 5.38 \\
\hline \multicolumn{9}{|c|}{$\begin{array}{l}\text { Composite surface }(0-15 \mathrm{~cm}) \text { soil samples from } \\
\text { experimental plots at Bakbes site }\end{array}$} \\
\hline Block 1 & 37 & 36 & 27 & Loam & 5.6 & 6.2 & 0.43 & 14.5 \\
\hline Block 2 & 35 & 34 & 31 & Clay loam & 5.6 & 6.32 & 0.44 & 16.24 \\
\hline Block 3 & 33 & 36 & 31 & Clay loam & 5.7 & 6.2 & 0.4 & 18.24 \\
\hline Mean & 35 & 35.3 & 29.6 & Clay loam & 5.63 & 6.24 & 0.42 & 16.32 \\
\hline \multicolumn{9}{|c|}{$\begin{array}{l}\text { Composite surface }(0-15 \mathrm{~cm}) \text { soil samples from } \\
\text { experimental plots at Ziyagn site }\end{array}$} \\
\hline Block 1 & 37 & 32 & 31 & Clay loam & 5 & 6.01 & 0.4 & 4.16 \\
\hline Block 2 & 37 & 32 & 31 & Clay loam & 4.9 & 5.87 & 0.4 & 4.22 \\
\hline Block 3 & 37 & 32 & 31 & Clay loam & 4.9 & 5.82 & 0.4 & 4.26 \\
\hline Mean & 37 & 32 & 31 & Clay loam & 4.93 & 5.9 & 0.4 & 4.21 \\
\hline
\end{tabular}

$\mathrm{OM}=$ Organic matter; Av. $\mathrm{P}=$ Available (Olsen) phosphorus

Soil reaction $(\mathbf{p H})$ : The results of the laboratory analysis for $\mathrm{pH}$ did not show a consistent relationship with the profiles studied at both sites. According to the classification of soil $\mathrm{pH}$ established by Jones [8], soil above $80 \mathrm{~cm}$ depth of the profile at the Bakbes site met the requirement of the strongly acidic soil class while the rest of the subsoil failed under the very strongly acidic soil category and very strongly acidic throughout the profile at the Ziyagn experimental site (Table 1). The mean 
$\mathrm{pH}$ values of the composite surface soils of Bakbes and Ziyagn experimental sites were moderately acidic (5.63) and very strongly acidic (4.93), respectively (Table 1). Generally, the pH of subsurface $(80-190 \mathrm{~cm})$ layers was lower than the $\mathrm{pH}$ of surface layer. This decrease in $\mathrm{pH}$ may be due to observed decrease in exchangeable $\mathrm{Ca}$ and $\mathrm{Mg}$ with depth (Table 2). The decrease in the basic cations concentrations with depth, in turn, may suggest that the downward movement of these constituents within the profile by leaching is very low.

Organic matter and total nitrogen: The organic matter $(\mathrm{OM})$ contents of the profiles (Table 1) decreased consistently with depth ranging from $6.27 \%$ at the surface layer to $0.76 \%$ at the extreme subsurface $(135-190 \mathrm{~cm})$ layer at the Bakbes site and from $6.18 \%$ at the surface layer to $1.59 \%$ at the extreme subsurface $(145-195 \mathrm{~cm})$ layer of the profile at the Ziyagn experimental site. On the other hand, the mean OM contents of the composite surface soils were 6.24 and $5.90 \%$ at Bakbes and Ziyagn sites, respectively. Based on the rating recommended by Tekalign [9] the mean OM contents of the composite surface soils at both sites met the limit for classification as high.

Similarly, the surface layer of the profile at Bakbes site and surface and subsurface $(30-85 \mathrm{~cm})$ layers of the profile at Ziyagn site had high OM contents, while the subsurface $(35-80 \mathrm{~cm})$ layer of the profile at Bakbes site was rated medium. On the other hand, the remaining layers of the profiles considered in the study had low OM contents except the extreme subsurface (135$190 \mathrm{~cm}$ ) layer of the profile at the Bakbes site which was rated as very low.

The findings of the present study pertaining to the distribution of soil OM with soil profile depth were similar with that of Dawit et al. [10] who indicated that the top soils are characterized by higher accumulation of mummified soil OM content which decreases with increasing soil depth. The highest OM contents recorded on the composite surface and surface layers of the profiles is apparently attributed to the contribution of crop residues, particularly roots, animal manure and green manure that are applied on to the surface and decomposed within the surface soil adding to the OM pool of the soils in the study area as explained by Dawit et al. [10].

The total $\mathrm{N}$ contents of the soil profiles decreased consistently with increasing soil depth and varied from 0.18 and $0.17 \%$ at the extreme layer to 0.57 and $0.61 \%$ at the surface layer at Bakbes and Ziyagn sites, respectively. The mean total $\mathrm{N}$ contents of the composite surface soils were $0.42 \%$ at Bakbes and $0.40 \%$ at the Ziyagn site. According to Tekalign [11], the total $\mathrm{N}$ contents of the surface and subsurface $(35-80 \mathrm{~cm})$ layers of the profile at the Bakbes site, the surface and subsurface (30$85 \mathrm{~cm}$ ) layers of the profile at the Ziyagn site and the mean total $\mathrm{N}$ contents of the composite surface soils of both sites fall under high whereas, the subsurface layers below $80 \mathrm{~cm}$ of the profile characterized at Bakbes and below $85 \mathrm{~cm}$ of that at the Ziyagn site were medium in their $\mathrm{N}$ contents. Apparently, the higher values of total $\mathrm{N}$ of the soil at both sites correspond to the higher values of OM suggesting the strong correlation between the two soil parameters as reported by many researchers [12,13].

Available soil phosphorus: The available phosphorus (P) contents of the profile at the Bakbes site decreased from $3.66 \mathrm{mg}$ $\mathrm{kg}$ at the surface layer to $1.14 \mathrm{mg} \mathrm{kg}$ at the subsurface $(80-135 \mathrm{~cm})$ layer and then increased again to $1.72 \mathrm{mg} \mathrm{kg}$ in the bottom $(135-190 \mathrm{~cm})$ layer of the profile (Table 1$).$ On the contrary, the available $\mathrm{P}$ contents of the profile at the Ziyagn experimental site increased consistently from $2.26 \mathrm{mg} \mathrm{kg}-1$ at the surface layer to $5.38 \mathrm{mg} \mathrm{kg}^{-1}$ in the bottom subsoil $(145-195 \mathrm{~cm})$ layer. The mean available $\mathrm{P}$ contents of the composite surface soils were 16.32 and $4.21 \mathrm{mg} \mathrm{kg-1}$ at Bakbes and Ziyagn experimental sites, respectively (Table 1 ). With regard to the rating of soil available $\mathrm{P}$ as determined by the Olsen method, Olsen et al. [6], Thus, the available P contents throughout the depth of the profiles of both sites except the bottom subsoil $(145-195 \mathrm{~cm})$ layer of the profile at the Ziyagn experimental site were rated as low and the bottom layer of the profile at Ziyagn (5.38 $\mathrm{mg} \mathrm{kg}^{-1}$ ) had medium available $\mathrm{P}$ content. According to the same author, the mean available $\mathrm{P}$ contents of the composite surface soils $(16.32$ and $4.21 \mathrm{mg}$ $\mathrm{kg}^{-1}$ ) could be rated as high and low at the Bakbes and Ziyagn experimental sites, respectively, where response of crops to $\mathrm{P}$ fertilization at low P level could be very high.

Except in the extreme subsurface layer, the content of $\mathrm{P}$ at Bakbes experimental site showed a decreasing trend with soil depth. This is in agreement with the findings of Tekalign et al. [11] who reported that topsoil P is usually greater than that in the subsoils due to sorption of the added $\mathrm{P}$, greater biological activity and accumulation of organic materials on the surface soils. On the other hand, Mohammed et al. [14] observed low levels of available $\mathrm{P}$ in the surface horizons of the cultivated at the Jelo sub catchment of the Chercher highlands in Eastern Ethiopia. Generally, low content of available P is a common characteristic of most of the soils in Ethiopia Wakene \& Heluf [15]. Such low level of available $\mathrm{P}$ could be due to $\mathrm{P}$ fixation by $\mathrm{Al}$ and Fe under the prevalence of strong acidity and low or no $\mathrm{P}$ inputs as organic and/or inorganic forms.

Exchangeable bases: Exchangeable Ca followed by Mg was the predominant cation in the exchange sites of both the profiles and the composite surface soil colloidal materials of the soils in both field experimental sites (Table 2). The exchangeable Ca contents decreased consistently with increasing soil depth at both of the study areas and the values varied from $7.41 \mathrm{cmol}(+)$

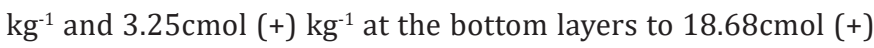
$\mathrm{kg}^{-1}$ and $9.97 \mathrm{cmol}^{(+)} \mathrm{kg}^{-1}$ at the surface layers of the soil profiles studied at the Bakbesand Ziyagn experimental sites, respectively. Similarly, exchangeable $\mathrm{Mg}$ contents decreased linearly with

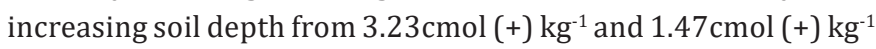
at the surface layers to $2.07 \mathrm{cmol}^{(+)} \mathrm{kg}^{-1}$ and $0.24 \mathrm{cmol}^{(+)} \mathrm{kg}^{-1}$ at the bottom subsurface layers at Bakbes and Ziyagn experimental sites, respectively (Table 2). 


\section{Agricultural Research \& Technology: Open Access Journal}

Table 2: Selected chemical properties of the soil profile and composite surface soil samples of the study areas.

\begin{tabular}{|c|c|c|c|c|c|c|c|c|c|c|c|c|}
\hline \multirow{2}{*}{$\begin{array}{c}\text { Depth } \\
(\mathrm{cm}) \\
\end{array}$} & \multicolumn{4}{|c|}{$\begin{array}{c}\text { Exchangeable } \\
\text { bases }\end{array}$} & \multicolumn{4}{|c|}{ acidity and CEC ( $\mathrm{cmol}(+) \mathrm{kg}^{-1}$} & \multicolumn{4}{|c|}{$\begin{array}{l}\text { Micronutrients } \\
\qquad\left(\mathrm{mg} \mathrm{kg}^{-1}\right)\end{array}$} \\
\hline & $\mathrm{Na}$ & $\mathrm{K}$ & $\mathrm{Ca}$ & $\mathrm{Mg}$ & $\mathrm{Al}$ & Acidity & CEC & PBS & $\mathrm{Fe}$ & $\mathrm{Mn}$ & $\mathrm{Zn}$ & $\mathrm{Cu}$ \\
\hline \multicolumn{13}{|c|}{ Soil profile at Bakbes site } \\
\hline $0-35$ & 0 & 0.49 & 18.68 & 3.23 & 0.24 & 0.68 & 42.28 & 53 & 59.01 & 15.4 & 4.14 & 0.57 \\
\hline $35-80$ & 0 & 0.29 & 14.19 & 3.07 & 0.32 & 0.46 & 30.7 & 57 & 49.8 & 7.57 & 1.86 & Trace \\
\hline $80-135$ & 0 & 0.51 & 9.16 & 2.61 & 0.64 & 0.61 & 19.61 & 63 & 8.6 & 1.72 & 0.51 & Trace \\
\hline $135-190$ & 0 & 0.56 & 7.41 & 2.07 & 0.72 & 0.91 & 17.08 & 59 & 3.3 & 0.27 & 0.79 & 1 \\
\hline \multicolumn{13}{|c|}{ Soil profile at Ziyagn site } \\
\hline $0-30$ & 0 & 0.14 & 9.97 & 1.47 & 1.16 & 1.22 & 23.71 & 49 & 42.95 & 29.11 & 3.68 & 0.2 \\
\hline $30-85$ & 0 & 0.09 & 6.02 & 0.45 & 1.36 & 2.51 & 20.29 & 32 & 32 & 9.27 & 1.25 & 0.51 \\
\hline $85-145$ & 0 & 0.09 & 4.42 & 0.43 & 1.6 & 1.52 & 18.3 & 27 & 32.67 & 0.9 & 1.13 & 0.67 \\
\hline 145-195 & 0 & 0.05 & 0.05 & 0.24 & 2.16 & 2.51 & 15.28 & 23 & 29.93 & 14.47 & 0.99 & 0.69 \\
\hline \multicolumn{13}{|c|}{$\begin{array}{l}\text { Composite surface }(0-15 \mathrm{~cm}) \text { soil samples } \\
\text { from experimental plots at Bakbes site }\end{array}$} \\
\hline Block 1 & 0.35 & 1.33 & 25.44 & 7.2 & 0.08 & 0.32 & 40.73 & 84 & 30.99 & 48.62 & 7.62 & 1.49 \\
\hline Block 2 & 0.22 & 1.48 & 27.34 & 7.36 & 0.16 & 0.32 & 39.56 & 92 & 30.55 & 47.95 & 6.53 & 1.65 \\
\hline Block 3 & 0.3 & 1.53 & 31.36 & 8.11 & 0.24 & 0.24 & 39.71 & 104 & 30.46 & 47.29 & 6.47 & 1.76 \\
\hline Mean & 0.29 & 1.46 & 28.04 & 7.56 & 0.16 & 0.29 & 40 & 93.3 & 30.6 & 7.95 & 6.87 & 1.6 \\
\hline \multicolumn{13}{|c|}{$\begin{array}{l}\text { Composite surface }(0-15 \mathrm{~cm}) \text { soil samples } \\
\text { from experimental plots at Ziyagn site }\end{array}$} \\
\hline Block 1 & 0.2 & 0.31 & 5.66 & 3.66 & 1.6 & 2.32 & 29.65 & 33 & 26.12 & 53.24 & 2.26 & 0.42 \\
\hline Block 1 & 0.24 & 0.33 & 4.56 & 3.8 & 1.36 & 2.16 & 30.69 & 29 & 26.96 & 55.04 & 2.58 & 0.62 \\
\hline Block 3 & 0.22 & 0.33 & 3.01 & 3.6 & 1.36 & 1.92 & 30.63 & 23 & 26.54 & 55.5 & 2.8 & 0.86 \\
\hline Mean & 0.22 & 0.32 & 4.41 & 3.68 & 1.44 & 2.13 & 30.32 & 28.32 & 6.54 & 54.59 & 2.54 & 0.63 \\
\hline
\end{tabular}

CEC = Cation exchange capacity PBS $=$ Percent base saturation.

Based on the classification set by FAO (2006), the concentrations of these two cations ( $\mathrm{Ca}$ and $\mathrm{Mg}$ ) fall under medium to high and under very low to medium at the Bakbes and Ziyagn experimental sites, respectively. The low contents of basic cations could be due to lower $\mathrm{pH}$ and higher exchangeable acidity in Ziyagn than at Bakbes site. These high contents of exchangeable $\mathrm{Ca}$ and $\mathrm{Mg}$ at the Bakbes site shows that the soil parent material primarily releases divalent cations in higher concentration and are retained for longer periods by the soil colloidal particles because of their higher selectivity coefficient over the monovalent cations. The mean exchangeable Ca contents

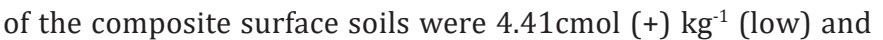
$28.04 \mathrm{cmol}^{(+)} \mathrm{kg}^{-1}$ (very high) at Ziyagn and Bakbes experimental sites, respectively. Similarly, the mean exchangeable Mg contents were $3.68 \mathrm{cmol}^{(+)} \mathrm{kg}^{-1}$ (high) and $7.56 \mathrm{cmol}(+) \mathrm{kg}^{-1}$ (high) at Ziyagn and Bakbes experimental sites, respectively (Table 2).

In all of the horizons of the profiles and composite surface soils, the proportions of the cations were in the order of $\mathrm{Ca}>\mathrm{Mg}$ $>\mathrm{K}>\mathrm{Na}$. There was no measurable quantity of exchangeable $\mathrm{Na}$ throughout the depths of both profiles which could be due to its highly soluble easily leached nature. On the other hand, exchangeable $\mathrm{K}$ contributed very small proportion and did not show any consistent trend with depth of the profile at Bakbes site and the values fall under low to moderate whereas, it decreased with increasing soil profile depth from 0.14 at the surface layer to 0.05 at the bottom $(145-195 \mathrm{~cm})$ layer of the profile at the Ziyagn experimental site (Table 2). The values of the exchangeable $\mathrm{K}$ at the Bakbes site fall under very low throughout the depth of the profile. The mean exchangeable Na contents of the composite surface soils were $0.22 \mathrm{cmol}^{(+)} \mathrm{kg}^{-1}$ (low) at Ziyagn and $0.29 \mathrm{cmol}$ (+) $\mathrm{kg}^{-1}$ (low) at Bakbes experimental sites and the mean exchangeable $\mathrm{K}$ contents were $0.32 \mathrm{cmol}^{(+)} \mathrm{kg}^{-1}$ (moderate) and $1.46 \mathrm{cmol}(+) \mathrm{kg}^{-1}$ (very high) at Ziyagn and Bakbes experimental sites, respectively.

\section{Exchangeable aluminum and exchangeable acidity}

The exchangeable aluminum (Al) contents of the profiles increased consistently with increasing soil depth at both sites of the study. Exchangeable $\mathrm{Al}$ contents varied from $0.24 \mathrm{cmol}(+)$ $\mathrm{kg}^{-1}$ and $1.16 \mathrm{cmol}(+) \mathrm{kg}^{-1}$ at the surface layers to $0.72 \mathrm{cmol} \mathrm{(+)}$ $\mathrm{kg}-1$ and $2.16 \mathrm{cmol}(+) \mathrm{kg}^{-1}$ at the bottom layers at Bakbes and Ziyagn experimental sites, respectively (Table 2). On the other hand, exchangeable acidity contents did not show any consistent trend with depth of profiles at both sites. The mean exchangeable Al contents of the composite surface soils were 0.16 and $1.4 \mathrm{cmol}$ (+) $\mathrm{kg}^{-1}$ at the Bakbes and Ziyagn experimental sites, respectively, while the mean exchangeable acidity contents of the composite surface soils were 0.29 at Bakbes site and $2.13 \mathrm{cmol}(+) \mathrm{kg}^{-1}$ at the Ziyagn site (Table 2). 
The lowest and the highest exchangeable acidity values were recorded at Bakbes and Ziyagn sites, respectively. The reason for the existence of higher concentration of exchangeable acidity at Ziyagn could be due to the release of certain organic acids from the functional groups of OM content of Ziyagn. Similar findings were also reported for the soil at the western slopes of Chilalo Mountain in the central Ethiopian highland by Ahmed [16].

\section{Cation exchange capacity}

As per the rating of soil characteristics, by Landon [17], The CEC contents of the profiles soil studied at the Bakbes and Ziyagn experimental sites ranged from $17.08 \mathrm{cmol}(+) \mathrm{kg}^{-1}$ and $15.28 \mathrm{cmol}$ $(+) \mathrm{kg}^{-1}$ at the bottom layers to $42.28 \mathrm{cmol}(+) \mathrm{kg}^{-1}$ and $23.71 \mathrm{cmol}$ $(+) \mathrm{kg}^{-1}$ at the surface layers, respectively (Table 2). Therefore, the rates fall under medium to very high at Bakbes and medium throughout the depth of the profile at Ziyagn experimental sites.

The mean CEC values of the composite surface soils were 40 and $30.32 \mathrm{cmol}(+) \mathrm{kg}^{-1}$ at Bakbes and Ziyagn experimental sites, respectively, falling under the high CEC at both experimental sites as per the rating established by Hazelton \& Murphy [18]. Generally, the values of CEC in those composite surface soils and in the soils of the profiles at both experimental sites indicated the presence of high potential for nutrient retention. The amounts of $\mathrm{OM}$ and clay as well as the type of the dominant clay mineral present might have been very important in contributing to the CEC values in the soils. Moreover, the high CEC values imply that the soil has high buffering capacity against induced chemical changes.

\section{Percent base saturation}

The values of percent base saturation (PBS) of the profile at Bakbes increased with depth of the profile from 53\% at the surface layer to $63 \%$ at subsoil $(80-135 \mathrm{~cm})$ layer and declined again to $59 \%$ at the extreme subsoil $(135-190 \mathrm{~cm}$ ) layer (Table 2). Based on the rating of Hazelton \& Murphy [18], the PBS values at the Bakbes experimental site fall under moderate throughout the depth of the profile except the subsoil $(80-135 \mathrm{~cm})$ layer which fall under high.The PBS contents at the Ziyagn site showed a decreasing trained from $49 \%$ at the surface layer to $23 \%$ at the bottom subsoil $(145-195 \mathrm{~cm}$ ) layer (Table 2 ) and the values fall under low PBS category throughout the profile depth except the surface $(0-30 \mathrm{~cm})$ layer which failed under moderate.

The mean PBS values of the composite surface soils were 28.3 and $93.3 \%$ at Ziyagn and Bakbes experimental sites, respectively, falling under low and very high respectively. Generally, the low values of PBS for the composite surface soil and the profile soils at the Ziyagn experimental site could be attributed to the low contents of exchangeable bases that go beyond CEC value for the reason already mentioned in the preceding section.

\section{Extractable micronutrients}

The lowest and the highest values in the soils of the profiles at Ziyagn and Bakbes experimental sites for Fe, Mn and $\mathrm{Zn}$ in $\mathrm{mg} \mathrm{kg}^{-1}$ were varied from 3.3 to 59.01 and 29.93 to
$42.95,0.27$ to 15.4 and 0.90 to $29.11,0.51$ to 4.14 and 0.99 to $3.68 \mathrm{mg} \mathrm{kg}^{-1}$, respectively. Generally, Fe contents at both study sites decreased consistently with increasing soil depth. While Mn contents decreased consistently with increasing soil depth at the Bakbes and Zn contents decreased with increasing soil depth at the Ziyagn site (Table 2). There was no measurable quantity of $\mathrm{Cu}$ in the profile layers at the Bakbes site except in the surface and the bottom sub soil $(135-190 \mathrm{~cm})$ layers of the profile. Whereas the $\mathrm{Cu}$ contents at the Ziyagn experimental site increased with increasing soil depth from 0.2 at surface and $0.69 \mathrm{mg} \mathrm{kg}^{-1}$ in the bottom subsoil $(145-195 \mathrm{~cm})$ layers of the profile. The mean $\mathrm{Fe}, \mathrm{Mn}, \mathrm{Zn}$ and $\mathrm{Cu}$ contents in the composite surface soils at the Bakbes and Ziyagn experimental sites were 30.6 and $26.54,47.95$ and 54.59, 6.87 and 2.54, 1.60 and $0.63 \mathrm{mg}$ $\mathrm{kg}^{-1}$, respectively (Table 2). According to the rating set by Jones (2003), Fe contents of the profile soils fall under high throughout the profile except the bottom subsoil $(135-190 \mathrm{~cm})$ layer which fall under medium at the Bakbes and high throughout the profile at the Ziyagn, experimental sites while Mn contents fall under medium throughout the profile except the bottom subsoil (135$190 \mathrm{~cm}$ ) layer which rated low at the Bakbes site while at Ziyagn site the values rated low to very high. Zinc contents of the profiles fall under medium to high at both study sites while $\mathrm{Cu}$ contents fall under low at Bakbes and under very low to low at Ziyagn, experimental sites. The mean values of $\mathrm{Cu}$ in the composite soils at both study sites of the profiles fall under low content.

Generally, low contents of $\mathrm{Cu}$ and $\mathrm{Zn}$ observed in the soils of the study areas were likely to cause limitation in crop yields as most plants are sensitive to $\mathrm{Cu}$ deficiency such as wheat, barley, maize, oats and vegetables. Heluf \& Wakene [19] also reported that micronutrients were highly influenced by different land use systems and significant variation was observed among the different land use systems. The $\mathrm{Cu}$ contents of most agricultural soils range from $2-100 \mathrm{mg} \mathrm{kg}^{-1}$ which is far greater than the amount measure in the soil of the present experimental sites. Therefore, the response of crops to $\mathrm{Cu}$ and $\mathrm{Zn}$ fertilization at such $\mathrm{Cu}$ and $\mathrm{Zn}$ levels could be high.

\section{Summary and Conclusion}

Soil fertility declines are forms of soil degradation adversely affecting sustainable crop production in Ethiopia. Thus, declining soil fertility presents a major challenge to bring about increased and sustainable productivity in order to feed the ever-increasing population of the country. To complement ongoing efforts in this line, a field experiment was conducted during the 2011 main cropping season under rainfed condition at Bakbes and Ziyagn areas of Shiebench District of Bench Maji Zone with the objective of soil fertility characterization based on their pysico-chemical properties.

In the present study, the increase in clay content and decrease in the sand and silt fractions with increasing soil depth might be attributed to the translocation of clay from the surface to subsurface horizons. The decrease in $\mathrm{pH}$ value with increasing 
soil depth at Bakbes site may be due to observed decrease in exchangeable $\mathrm{Ca}$ and $\mathrm{Mg}$ with depth. The decrease in the basic cations concentrations with depth, in turn, may suggest that the downward movement of these constituents within the profile by leaching is very low.

The highest OM contents recorded at Bakbes site is apparently attributed to the contribution of crop residues, particularly roots, animal manure and green manure that are applied on to the surface and decomposed within the surface soil adding to the OM pool of the soils. Apparently, the higher values of total $\mathrm{N}$ of the soil at both sites correspond to the higher values of OM suggesting the strong correlation between the two soil parameters. The decrease in P content with depth could be due to sorption of the added $\mathrm{P}$, greater biological activity and accumulation of organic materials on the surface soils of Bakbes site. Low level of available $\mathrm{P}$ at Ziyagn site could be due to $\mathrm{P}$ fixation by $\mathrm{Al}$ and Fe under the prevalence of strong acidity and low or no P inputs as organic and/or inorganic forms.

The low contents of basic cations could be due to lower $\mathrm{pH}$ and higher exchangeable acidity in Ziyagn than at Bakbes site. These high contents of exchangeable $\mathrm{Ca}$ and $\mathrm{Mg}$ at the Bakbes site shows that the soil parent material primarily releases divalent cations in higher concentration and are retained for longer periods by the soil colloidal particles because of their higher selectivity coefficient over the monovalent cations. The reason for the existence of higher concentration of exchangeable acidity at Ziyagn could be due to the release of certain organic acids from the functional groups of OM content of Ziyagn

The high values of CEC in those composite surface soils and in the soils of the profiles at both experimental sites indicated the presence of high potential for nutrient retention. Moreover, the high CEC values imply that the soil has high buffering capacity against induced chemical changes. The low values of PBS for the composite surface soil and the profile soils at the Ziyagn experimental site could be attributed to the low contents of exchangeable bases that go beyond CEC value. The low contents of $\mathrm{Cu}$ and $\mathrm{Zn}$ observed in the soils of the study areas were likely to cause limitation in crop yields as most plants are sensitive to Cu deficiency.

In conclusion, the results of the current study provides; the use of various types and methods of amendments in combination with inorganic fertilizers including the micro nutrients and use of non-acidifying fertilizers are suggested to minimize the negative effects of soil acidity.

\section{Acknowledgements}

The author would like to express her special appreciation and deepest thanks to her Major Advisor, Professor Heluf Gebrekidan for the his keen interest, consistent guidance, critical remarks, and encouragement starting from proposal writing to the completion of the thesis work. She shared with him his accumulated professional experiences and he was cooperative throughout the study period. She also extends her deepest gratitude to her Co-Advisor Dr. Wassie Haile for his unreserved advice, comments, suggestions, and encouragement starting from proposal writing to the completion of the thesis work.

The author extends her special thanks to AGRA and to the ministry of agriculture who helped her to involve in the graduate study by providing the newly introduced fertilizer for the completion of her work. The author extends her special thanks to the Bureau of Agricultural and Rural Development of the Southern Nations Nationality and People's Regional State and Haramaya University for providing her the opportunity to pursue her graduate study at Haramaya University. The National Soil Testing Laboratory staffs are also highly appreciated for their cooperation during the analysis of some of the soil physical, chemical and plant tissue parameters.

The author expresses her deep sense of appreciation and heartfelt thanks to her beloved husband, Samuel Syiraji, for his patience and affectionate love and unreserved advice, comments, and encouragement starting from proposal writing to the completion of the thesis work. Special thanks are delivered to her friends for their unlimited support and encouragement throughout the field experiment work.

Her deepest gratitude goes to her family's father, Belay Abesha, mother, Seble W/Michael, her sisters and brothers who offered her comprehensive support, unreserved moral and special treatment not only for this work but also throughout her life. Without their special treatment, encouragement and love her work would not have been successful. If she forget someone unmentioned, it is her mind not her heart to be blamed.

\section{References}

1. Eyasu Elias (2002) Farmers Perception of Soil Fertility Changes and Management. Institute for Sustainable Development, Addis Ababa, Ethiopia.

2. FAO-WRB (Food and Agriculture Organization-World Reference Base for Sciences) (2006) A framework for international classification, correlation and communication. $\left(2^{\text {nd }}\right.$ edn), World science Reports No. 103. FAO, Rome, Italy.

3. Fassil Kelemework, Teklu Erkosa, Teklu Tesfaye, Assefa Gizaw (2000) On farm demonstration of improved durum wheat varieties under enhanced drainage on Acid soils in Central highlands of Ethiopia. In: The Eleventh Regional Wheat Workshop for Eastern, Central and Southern Africa. CIMMYT, Addis Ababa Ethiopa.

4. Bekele Hundie, H Verkuiji, W Mawangi, D G Tanner (2000) Adaptation of improved wheat technologies in Addaba and Dodolaworedas of the Bale highlands, Ethiopia CIMMYT/EARO, Addis Ababa, Ethiopia.

5. Sahlemedhin Sertsu, Taye Bekele (2000) Procedures for Soil and Plant Analysis. National Soil Research center, Ethiopian Agricultural Research organization, Ethiopia.

6. Olsen SR, Cole CV, Watanabe FS, Dean LA (1954) Estimation of available phosphorus in soil by extraction with sodium bicarbonate. USDA circular.

7. Okalebo JR, Gathua KW, Woomer PL (2002) Laboratory methods of soil and plant analyses: a working manual. $\left(2^{\text {nd }} e d n\right)$, TSBF-CIAT and SACRED Africa, Nairobi, Kenya. 
8. Jones JB (2003) Agronomic Handbook: Management of crops, soils and their fertility. CRC Press LLC, Boca Raton, FL, USA.

9. Tekalign Tadesse (1991) Soil, plant, water, fertilizer, animal manure and compost analysis manual. Working Document No.B13. Soil Science and Plant Nutrition Section, International Livestock Center for Africa, Addis Ababa, Ethiopia.

10. Dawit Solomon, F Fritzsche, Tekalign Mamo, J Lehmann, W Zech (2002) Soil organic matter composition in the sub-humid Ethiopian highlands as influenced by deforestation and agricultural management. Soil Sci Soc Am J 66(1): 68-82.

11. Tekalign Mamo, Haque I (1991) Phosphorus status of some Ethiopian soils, II.Forms and distribution of inorganic phosphorus. Tropical Agriculture 68(1): 2-8.

12. Taye Kufa, Mesfin Abebe, Paulos Dubale (2003) Contribution of organic amendment to physico-chemical conditions of coffee nursery media. In: Tilahun Amede, Eylachew Zewdie (Eds.), Challenges of land Degradation to Agriculture in Ethiopia. 80 Proceedings of the 6th ESSS conference, Ethiopian Society of Soil Science.

13. Nega Emiru (2006) Land Use Changes and Their Effects on Soil Physical and Chemical Properties in Senbat Sub-Watershed, Western Ethiopia. MSc Thesis, Alemaya University, Ethiopia.
14. Mohammed A, Roux PAL, Barker CH, Heluf G (2005) Soils of Jelo Microcatchment in the Chercher highlands of Eastern Ethiopia: Morphological and Physicochemical Properties. Ethiopian Journal of Natural Resources 7(1): 55-81.

15. Wakene Negassa, Heluf Gebrekidan (2003) Forms of phosphorus and status of available micronutrients under different land-use systems of Alfisols in Bako area of Ethiopia. Ethiopian Journal of Natural Resources 5(1): 17-37.

16. Ahmed Hussen (2002) Assessment of Spatial Variability of Some Physcio-chemical Properties of Soils under Different Elevations and Land Use Systems in the Western Slopes of Mount Chilalo, Arsi. MSc. Thesis, Alemaya University, Ethiopia.

17. Landon JR (1991) Booker tropical soil manual: A Handbook for Soil Survey and Agricultural Land Evaluation in the Tropics and Subtropics. Longman Scientific and Technical, Essex, New York, USA.

18. Hazelton P, Murphy B (2007) Interpreting soil test results: What do all the numbers mean? ( $\left.2^{\text {nd }} e d n\right)$, CSIRO publishing, Australia.

19. Heluf Gebrekidan, Wakene Negasa (2006) Impact of land use and management practices on chemical properties of some soils of Bako area, Wetern Ethiopia. Ethiopian Journal of Natural Resources 8(2): 177-197.

Your next submission with Juniper Publishers
will reach you the below assets
- Quality Editorial service
- Swift Peer Review
- Reprints availability
- E-prints Service
- Manuscript Podcast for convenient understanding
- Global attainment for your research
- Manuscript accessibility in different formats
( Pdf, E-pub, Full Text, Audio)
- Unceasing customer service
Track the below URL for one-step submission
https://juniperpublishers.com/online-submission.php

